\title{
Pengembangan Radio MBS 107.80 FM Berbasis Aplikasi Android
}

\author{
Novia Widyastuti ${ }^{1}$ \\ ${ }^{1}$ FTI Radio
}

\begin{abstract}
Radio of Da'wah and Preaching (MBS) is a Community Radio with UIN Walisongo. The research method used in this study is the ADDIE method. while the object under study is the ease offunding the feasibility of an Android-based radio streaming application. The advantage of this radio application product is its easy operational procedures. After being designed in such a way as in the initial product design discussion, in operation it only needs to run the ZaraRadio application as its main software for broadcasting, then the broadcaster also runs an edcast application to transfer audio to the streamer so that it can transfer to the Android application. While the weakness of this streaming product is the sound that is heard on the streaming channel has a delay of about 15-20 seconds. Another weakness is the internet network system in edcast applications that do not support using a proxy internet network so researchers use the internet modulator demodulator network (modem) to run streaming radio on the edcast application. Another weakness is that the previous network on MBS.FM radio streaming was limited, only 100 listeners at the same time.
\end{abstract}

Keywords: Radio Streaming Application, Android, and ADDIE.

\begin{abstract}
Abstrak
Radio Mitra Berdakwah dan Bersholawat (MBS) adalah Radio Komunitas yang ada UIN Walisongo. Metode penelitian yang digunakan dalam penelitian ini adalah metode ADDIE. sedangkan objek yang diteliti adalah kemudahan dana kelayakan aplikasi radio streaming berbasis Android. Kelebihan dari produk aplikasi radio ini ialah pada prosedur operasionalnya yang mudah. Setelah didesain sedemikian rupa sebagaimana pada pembahasan desain awal produk, pada operasionalnya hanya tinggal menjalankan aplikasi ZaraRadio sebagai software utamanya dalam melakukan siaran, kemudian penyiar juga menjalankan aplikasi edcast untuk mentransfer audio ke streamer agar dapat mentransfer ke aplikasi android. Sedangkan kelemahan pada produk streaming ini ialah suara yang didengarkan pada channel streaming mengalami delay yaitu sekitar 15-20 detik. Kelemahan lain yaitu system jaringan internet pada aplikasi edcast yang tidak mendukung untuk menggunakan jaringan internet mikrotik sehingga peneliti menggunakan jaringan internet modulator demodulator (modem) untuk menjalankan streaming radio pada aplikasi edcast. Kelemahan yang lain yaitu jaringan sebelumnya pada streaming radio MBS.FM terbatas, hanya 100 pendengar saja diwaktu bersamaan.
\end{abstract}

Kata Kunci: Aplikasi Radio Streaming, Android, dan ADDIE.

ISSN 2715-0143 (online) ISSN 2714-9048 (print)

http://journal.walisongo.ac.id/index.php/jit/index

WJIT : Walisongo Journal of Information Technology - Vol.1 No. 2 (2019) 


\section{A. Latar Belakang}

Seiring berjalannya waktu, teknologi tumbuh berkembang sejalan dengan kebutuhan-kebutuhan manusia yang tiada habisnya. Saat ini Internet menjadi hal yang paling penting dalam kehidupan sehari-hari, banyak hal yang dapat dilakukan melalui internet. Hal itu sejalan juga dengan perkembangan aplikasi yang berbasis internet. Salah satu aplikasi yang dibutuhkan dalam perkembangannya antara lain adalah aplikasi streaming radio online. Dahulu sebelum berkembangnya teknologi dan aplikasi streaming, mendengarkan radio harus dengan radio yang nyata, namun pada kenyataanya banyak kendala yang diperoleh, seperti buruknya penerimaan gelombang frekuensi radio maka berimbas pada saat mendengarkan siaran radio terganggu karena siarannya tidak menjangkau. Penyiaran yang dilakukan dengan radio internet atau streaming akan lebih efektif, karena layanan radio internet dapat diakses lebih luas, hingga dari belahan dunia manapun, Misalnya orang dapat mendengarkan stasiun radio Indonesia walupun sedang berada diluar Indonesia. Hal ini akan mempermudah pendengar, karena lebih leluasa memilih layanan yang diinginkan, serta informasi yang didapat lebih banyak.

Banyaknya keunggulan dan karakteristik radio yang membuat khalayak tertarik dan tetap bertahan hingga tahun 2017 ini membuat media penyiaran radio semakin marak berkembang dan menunjukan eksistensinya, sehingga persaingan menjadi semakin ketat. Tidak hanya dengan media penyiaran radio saja tetapi juga dengan media lain, seperti televise, media cetak, dan media sosial.

Persaingan yang semakin ketat membuat media penyiaran radio harus semakin kreatif dan berfikir keras dalam memberikan informasi yang sedang terjadi dan dibutuhkan masyarakat yang actual, jelas, serta cepat. dalam mendapatkan informasi yang cepat dan mudah, masyarakat saat ini memanfaatkan fasilitas yang ada yaitu gadget yang didalmnya terdapat fitur aplikasi yang mendukung untuk mendapatkan informasi yang mereka butuhkan.

Memasuki era tekhnologi informasi, para pemilik stasiun radiopun berlomba untuk menarik perhatian para pengguna internet. Maka dibuatlah siaran-siaran radio yang disiarkan melalui media internet secara online. Siaran semacam ini disebut dengan streaming. Siaran radio online ini menyasar para pengguna internet yang sangat banyak di Indonesia.

Pada era globalisasi seperti saat ini, informasi bisa diperoleh siapa saja dengan mudah. Masyarakat dapat saling berinteraksi tanpa hambatan yang berarti. Terlebih, dengan kemajuan teknologi informasi dan komunikasi, semuanya menjadi terasa semakin dekat. Inilah salah satu hal yang membuat para ahli menjuluki era sekarang ini sebagai era informasi (Muhtadi, 2012: 5)

Radio siaran mulai masuk di Indonesia pada saat penjajahan belanda pada tanggal 16 Juli 1925 
yang bernama Bataviase Radio Vereniging atau BRV di Batavia atau Jakarta tempo dulu. Selama masa penjajahan Belanda, stasiun radio yang beroperasi adalah milik swasta. Setelah Bataviase Radio Vereniging atau BRV didirikan, berbagai stasiun radio lain pun mulai menjamur. Sebelum Orde Reformasi lahir, sesuai dengan sistem komunikasi Indonesia dan sistem jurnalistik di Indonesia yang dianut saat itu, berbagai program jurnalisme radio atau jurnalistik radio dilakukan sepenuhnya oleh Radio Republik Indonesia. Radio siaran swasta hanya berperan sebagai media hiburan yakni dengan memutar lagu-lagu, sandiwara radio, dan lain-lain.

Hingga pada akhirnya, radio mengalami perkembangan hingga saat ini. Walaupun dengan kekurangan dan kelebihan pada radio, media komunikasi ini diakui sebagai media massa yang dapat diandalkan karena cukup efektif dalam menyampaikan pesan atau informasi selama radio dapat bertahan adanya perkembangan zaman yang semakin pesat ini. Dengan adanya perkembangan radio yang mengikuti zaman yang semakin pesat perkembangannya, maka radio ini dibedakan hingga menjadi beberapa jenis radio. Adapun jenis-jenis radio di Indonesia yang telah diakui adalah sebagai berikut: Pertama Radio publik ini biasanya disebut sebagai radio pemerintahan, karena radio ini dipegang penuh oleh badan pemerintahan yang pengelolahnya adalah salah satu departemen di badan pemerintahan yang sudah disetujui dan diatur dalam perundang-undangan. Sehingga, dapat dikatakan bahwa secara penuh dan secara tegas, bahwa radio publik ini dipimpin dan diolah oleh pemerintahan. Kedua Radio Swasta Berbeda halnya dengan radio publik yang sepenuhnya dipegang oleh pemerintahan. Bahwa radio swasta ini merupakan radio yang dimiliki oleh perorangan yang sifatnya komersil. Sehingga, sumber penghasilan untuk operasional radio swasta ini sepenuhnya berasal dari iklan. Walaupun demikian, radio swasta masih berada di bawah perundangundangan mengenai penyiaran yang disepakati melalui lisensi pemerintahan. Ketiga Radio berlangganan ini merupakan radio yang sejenis dengan radio publik. Yang mana radio tersebut dipegang kendali oleh suatu lembaga yang bernama Lembaga Penyiaran Berlangganan. Lembaga ini, merupakan lembaga penyiaran yang berbentuk badan hukum di Indonesia. Yang mana lembaga tersebut merupakan penyelenggara jasa penyiaran berlangganan yang sudah diakui oleh izin penyelenggara penyiaran berlangganan. Sehingga, Lembaga Penyiaran Berlangganan ini dapat memancarluaskan dan menyebarkan siaran kepada masyarakat dari radio yang berlangganan. Keempat Radio Komunitas Jika radio publik dipegang pemerintahan dan radio swasta dipegang perseorangan, berbeda dengan radio komunitas yang 
dipegang bersama-bersama tapi nonpemerintahan.

Radio Mitra Berdakwah dan Bersholawat (MBS) adalah Radio Komunitas yang ada di Fakultas Dakwah dan Komunikasi UIN Walisongo Semarang dengan Frequensi 107.8 Mhz. Pada awalnya Radio MBS merupakan tempat Praktikum Mahasiswa untuk mengembangkan kemampuannya dibidang kepenyiaran. Setelah berjalan beberapa waktu, Radio MBS meningkatkan kemampuannya kejenjang yang lebih tinggi yaitu ingin memberikan hiburan yang positif kepada masyarakat yang ada disekitar stasiun radio (Fikri Amrullah : 2017). Karena keterbatasan jangkauan frekuensi yang dimiliki untuk mendengarkan radio MBS, media informan mengatakan bahwa mereka tidak dapat mendengarkan radio MBS karna tidak terjangkau di wilayah tertentu.

Berdasarkan Latar belakang tersebut maka penulis ingin membuat dan meneliti lebih lanjut tentang Aplikasi radio streaming berbasis android pada radio MBS.FM. Untuk mengakses aplikasi yang penulis buat cukup mendownload aplikasi tersebut menggunakan gadget mereka, dengan demikian pendengar lebih mudah dan leluasa mendengarkan radio MBS.FM.

Judul yang penulis angkat adalah "Pengembangan Radio MBS 107.80 FM Berdasarkan Aplikasi Android" diharapkan penelitian ini dapat mempermudah pendengar untuk mendengarkan radio MBS.FM dengan jangkauan frekuensi yang baik.

\section{B. Tinjauan Pustaka}

Skripsi Masy Ari Ulinuha, M.T Fakultas Dakwah dan Komunikasi UIN Walisongo Semarang, dengan judul "PERANCANGAN STASIUN RADIO ONLINE MBS FM FAKULTAS DAKWAH DAN KOMUNIKASI IAIN WALISONGO". Dalam skripsinya ulinuha menggunakan jenis penelitian RnD (Research and Development) penelitian ini menggunakan pendekatan penelitian rekayasa yang berupa Forward Enginering. Pada skripsi ini peneliti merancang pembuatan blog sekaligus live streaming. radio MBS.FM awalnya hanya menggunakan frequensi sinyal pemancar saja, lalu dalam skripsi ini radio MBS.FM dikembangkan menjadi radio streaming yang dapat diakses melalui jaringan internet.

\section{Metode Penelitian}

Penelitian ini adalah penelitian pengembangan atau dalam Bahasa Inggrisnya Research and Developmen $(R \& D)$ yaitu metode penilitian yang digunakan untuk menghasilkan produk tertentu dan menguji keefektifan produk tertentu (Sugiyono 2009 : 407). Sukmadinata (2008), mengemukakan penelitian dan pengembangan merupakan pendekatan penelitian untuk menghasilkan produk baru atau menyempurnakan produk yang telah ada. Produk yang dihasilkan bisa berbentuk software ataupun hardware seperti buku, modul, paket, program pembelajaran ataupun alat bantu belajar. 
Penelitian dan pengembangan berbeda dengan penelitian biasa yang hanya menghasilkan saran-saran bagi perbaikan, penelitian dan pengembangan menghasilkan produk yang langsung bisa digunakan. (Haryati, 2012)

Produk yang dikembangkan pada penelitian ini berupa Aplikasi berbasis Android untuk Radio Komunitas MBS (Mitra Bersholawat), adapun langkah langkah penelitian yang digunakan oleh peneliti adalah langkah-langkah penelitian dan pengembangan model ADDIE yang dikembangkan oleh Dick and Carry 1996, yaitu model Analisis, Desain, Development (pengembangan), Implementation (implementasi), dan Evaluasi

\section{LANDASAN TEORI}

Android adalah system operasi yang berbasis linux untuk telepon seluler seperti telepon pintar dan computer tablet, android menyediakan platform terbuka bagi para pengembangang untuk menciptakan aplikasi mereka sendiri untuk digunakan oleh bermacammacam peranti bergerak, awalnya Google Inch. Membeli Android Inch, pendatang baru yang membuat peranti lunak untuk ponsel, kemudian untuk mengembangkan android dibentuklah Open Handset Alliance, konsorsium dari 34 perusahaan peranti keras, peranti lunak, dan telekomunikasi, termasuk google, HTC, INTEL, Motorola, Qualcomm, TMobile, Nvidia. (sa'di : 2)
Adapun definisi Android menurut beberapa para ahli dijabarkan sebagai berikut:

1. Menurut Teguh Arifianto (2011 : 1), android merupakan perangkat bergerak pada sistem operasi untuk telepon seluler yang berbasis linux.

2. Menurut Hermawan (2011：1), Android merupakan OS (Operating System) Mobile yang tumbuh ditengah OS lainnya yang berkembang dewasa ini. OS lainnya seperti Windows Mobile, i-Phone OS, Symbian, dan masih banyak lagi. Akan tetapi, OS yang ada ini berjalan dengan memprioritaskan aplikasi inti yang dibangun sendiri tanpa melihat potensi yang cukup besar dari aplikasi pihak ketiga. Oleh karena itu, adanya keterbatasan dari aplikasi pihak ketiga untuk mendapatkan data asli ponsel, berkomunikasi antar proses serta keterbatasan distribusi aplikasi pihak ketiga untuk platform mereka.

3. Android menurut Nazaruddin (2012 : 1) merupakan sistem operasi untuk telepon seluler yang berbasis Linux. Android menyediakan platform terbuka bagi para pengembang untuk menciptakan aplikasi mereka sendiri untuk digunakan oleh bermacam peranti bergerak. Android umum digunakan di smartphone dan juga tablet PC. Fungsinya sama seperti sistem operasi Symbian di Nokia, iOS di Apple dan BlackBerry OS. 
Android versi 1.0 dikeluarkan tanggal 23 September 2008, versi 1.1 pertama kali digunakan di mobile phone (T1). Versi 1.5 (Cupcake) muncul Mei2009 yang mendukung soft keyboard hingga versi terakhir:

a. Android Versi 1.1

OS Android versi 1.1 dirilis pada tanggal 9 Maret 2009 oleh perusahaan Google. Dilengkapi dan disupport oleh Google Mail Service dengan pembaruan yang sangat bagus pada aplikasi, jam alarm, voice search (pencarian suara), pengiriman pesan dengan Gmail, dan pemberitahuan email

b. Android Versi 1.5 Cup Cake

Android Cup Cake dirilis pada pertengahan Mei 2009, masih oleh Google Inc. Android ini dilengkapi software development kit dengan berbagai pembaharuan termasuk penambahan beberapa fitur antara lain yakni kemampuan merekam dan menonton video dengan modus kamera, mengunggah video ke Youtube, upload gambar ke Picasa langsung dari telepon, serta mendapat dukungan Bluetooth A2DP.

c. Android Versi 1.6 Donut

Android Donut di rilis pada September 2009 menampilkan proses pencarian yang lebih baik dibandingkan versi-versi sebelumnya. Selain itu Android Donut memiliki fitur-fitur tambahan seperti galeri yang memungkinkan pengguna untuk memilih foto yang akan dihapus, kamera, camcorder dan galeri yang dintegrasikan, Text-to-speech engine, kemampuan dial kontak, teknologi text to change speech. Android Donut juga dilengkapi baterai indikator, dan kontrol applet VPN.

d. Android Versi 2.0/2.1 Éclair

Android Eclair dirilis pada 3 Desember 2009. Perubahan yang ada antara lain adalah pengoptimalan hardware, peningkatan Google Maps 3.1.2, perubahan UI dengan browser baru dan dukungan HTML5, daftar kontak yang baru, dukungan flash untuk kamera 3,2 MP, digital Zoom, dan Bluetooth 2.1. Android Eclair merupakan Adroid pertama yang mulai dipakai oleh banyak smartphone, fitur utama Eclair yaitu perubahan total struktur dan tampilan user interface.

e. Android Versi 2.2 Froyo (Frozen Yogurt)

Android Froyo dirilis pada 20 mei 2012. Adroid versi ini memiliki kecepatan kinerja dan aplikasi 2 sampai 5 kali dari versi-versi sebelumnya. Selain itu ada penambahan fitur-fitur baru seperti dukungan Adobe Flash 10.1, intergrasi V8 JavaScript engine yang dipakai Google Chrome yang mempercepat kemampuan rendering pada browser, pemasangan aplikasi dalam SD Card, kemampuan WiFi Hotspot portable.

f. Android Versi 2.3 Gingerbread

Android Gingerbread di rilis pada 6 Desember 2010. Perubahanperubahan umum yang didapat dari Android versi ini antara lain peningkatan kemampuan permainan (gaming), peningkatan fungsi copy paste, layar antar muka (User Interface) didesain ulang, dukungan format video VP8 dan WebM, efek audio baru (reverb, equalization, 
headphone virtualization, dan bass boost), dukungan kemampuan Near Field Communication (NFC), dan dukungan jumlah kamera yang lebih dari satu.

g. Android Versi 3.0/3.1 Honeycomb

Android Honeycomb di rilis pada awal 2012. Merupakan versi Android yang dirancang khusus untuk device dengan layar besar seperti Tablet PC. Fitur baru yang ada pada Android Honeycomb antara lain yaitu dukunganterhadap prosessor multicore dan grafis dengan hardware acceleration. User Interface pada Honeycomb juga berbeda karena sudah didesain untuk tablet. Tablet pertama yang memakai Honeycomb adalah tablet Motorola Xoom yang dirilis bulan Februari 2011.

h. Android Versi 4.0 ICS (Ice Cream Sandwich)

Android Ice Cream Sandwich diumumkan secara resmi pada $10 \mathrm{Mei}$ 2011 di ajang Google I/O Developer Conference (San Francisco), pihak Google mengklaim Android Ice Cream Sandwich akan dapat digunakan baik di smartphone ataupun tablet. Android Ice Cream Sandwich membawa fitur Honeycomb untuk smartphone serta ada penambahan fitur baru seperti membuka kunci dengan pengenalan wajah, jaringan data pemantauan penggunaan dan kontrol , dan berbagi informasi dengan menggunakan NFC.

i. Android Versi 4.1 Jelly Bean

Android Jelly Bean juga diluncurkan pada acara Google I/O 10 Mei 2011 yang lalu. Android versi ini membawa sejumlah keunggulan dan fitur baru, diantaranya peningkatkan input keyboard, desain baru fitur pencarian, UI yang baru dan pencarian melalui Voice Search yang lebih cepat. Versi ini juga dilengkapi Google Now yang dapat memberikan informasi yang tepat pada waktu yang tepat pula.

Salah satu kemampuannya adalah dapat mengetahui informasi cuaca, lalu-lintas, ataupun hasil pertandingan olahraga. Sistem operasi Android Jelly Bean 4.1 pertama kali digunakan dalam produk tablet Asus, yakni Google Nexus 7.

j. Android Versi 4.2 Jelly Bean

Fitur photo sphere untuk panaroma, daydream sebagai screensaver, power control, lock screen widget, menjalankan banyak user (dalam tablet saja), widget terbaru. Android 4.2 Pertama kali dikenalkan melalui LG Google Nexus 4. k. Android Versi 4.4 Kit Kat

Dan versi 4.4 ini adalah versi paling baru dari Android yang membawa semua perubahan dari versi-versi sebelumnya, resmi di luncurkan pada tanggal 31 oktober 2013.

l. Android Versi 5.0 Lollipop

Android versi 5.0 Lollipop

dirilis Google pada tanggal 15 Oktober 2014, OS Android versi ini adalah update terbesar dalam sepanjang sejarah pengembangan sistem operasi Android. Sangat banyak sekali fitur terbaru pada Android versi 5.0 seperti material design menggunakan gaya baru dengan konsep seperti kertas dan tinta, didukung dengan prosesor 64- 
bit seperti ARMv8 64-bit, AMD64/x86-64, dan MIPS64. Dukungan prosesor dan arsitektur 64bit ini diharapkan dapat meningkatkan kinerja Android 5.0 Lollipop secara signifikan dan mendukung penggunaaan memori RAM hingga lebih dari 4GB.

m. Android Versi 6.0 Marshmallow

Android versi 6.0 sering juga disebut Android M dirilis pada bulan Oktober 2015, memiliki fitur yang lebih baik dari OS sebelummnya dengan penyempurnaan inkremental, juga penambahan fitur lainnya. Hal paling menonjol pada Androil Marsmallow ini adalah adanya skema manajemen baterai yang bernama Doze yang memiliki fungsi mengurangi dan meredam aktivitas aplikasi di belakang latar sehingga dapat mengefisienkan daya baterai. OS android ini juga memiliki fitur pengenalan sidik jari untuk membuka perangkat.

n. Android Versi 7.0 Nougat

Android 7.0 atau Android N dirilis pada tanggal 23 Agustus 2016, memiliki banyak fitur terbaru seperti memiliki dukungan Multi-Window, direct reply, Quick Setting yang lebih dinamis, panel setting yang lebih informatif, memiliki menu Recent App yang lebih simpel dan mudah.

\section{E. Pengembangan Radio Mbs 107.80 Fm Berbasis Aplikasi Android}

Prosedur pelaksanaan penelitian pengembangan dari ADDIE dibatasi dan disesuaikann dengan kebutuhan peneliti. Penelitian pengembangan menggunakan desain ADDIE dibatasi sampai tahap pengembangan.

1. Analisis

Pada tahap ini peneliti menganalisis kebutuhan yang diperlukan oleh pengguna yaitu dengan melihat potensi dan masalah yang ada di lokasi penelitian. Potensi yang dimiliki oleh radio MBS.FM 107.80 Fakultas Dakwah dan Komunikasi UIN Walisongo semarang adalah sebagai sarana pembelajaran bidang penyiaran radio sekaligus ajang kreatifitas serta pengembangan bakat dan minat mahasiswa dalam bidang broadcasting. Sedangkan masalah yang terdapat di radio MBS.FM 107.80 jangkauan siaran yang terbatas karena radio MBS merupakan radio komunitas yang frekuensinya hanya mencapai 2,5 kilometer, dan radio MBS saat ini sudah menjadi radio streaming yang bisa diakses melalui web fakultas atau link streamingnya langsung, namun banyak pndengar radio MBS yang mengeluh terkait kurang efektifnya mengakses radio streaming tersebut. Inilah yang menjadi alasan utama kenapa peneliti ingin membuat aplikasi android radio MBS.FM.

Setelah potensi dan masalah dapat ditunjukan secara factual, maka selanjutnya dikumpulkan berbagai informasi yang dapat digunakan sebagai bahan untuk perencanaan produk yang diharapkan dapat mengatasi masalah tersebut. Dalam rangka pengumpulan informasi, peneliti mengunjungi tempat penyiaran radio MBS.FM 107.80 untuk melihat secara langsung bagaimana 
proses siaran dilakukan serta berkomunikasi dengan pihak-pihak terkait terutama dengan ketua siar radio MBS.FM, serta mempersiapkan desain aplikasi android radio MBS.FM.

2. Desain

Desain merupakan langkah kedua ADDIE. Pembuatan aplikasi android radio MBS.FM ini menggunakan web khusus untuk membuat aplikasi yang bernama Apps Geyser. Sebelum membuat aplikasi tersebut langkah pertama yang harus dilakukan adalah membuat akun Apps Geyser untuk bisa mengakses website pembuatan aplikasi tersebut.

3. Developmen

Tahap yang selanjutnya yaitu tahap pembuatan aplikasi radio streaming berbasis android. Dengan mengacu 4 prinsip kriteria aplikasi radio streaming berbasis android, yaitu : kesesuaian, kemudahan, kemenarikan, dan kemanfaatan. Tahapan ini meliputi:

a. Proses pembuatan komponenkomponen aplikasi radio streaming berbasis android yang meliputi:
1. template (latar belakang)

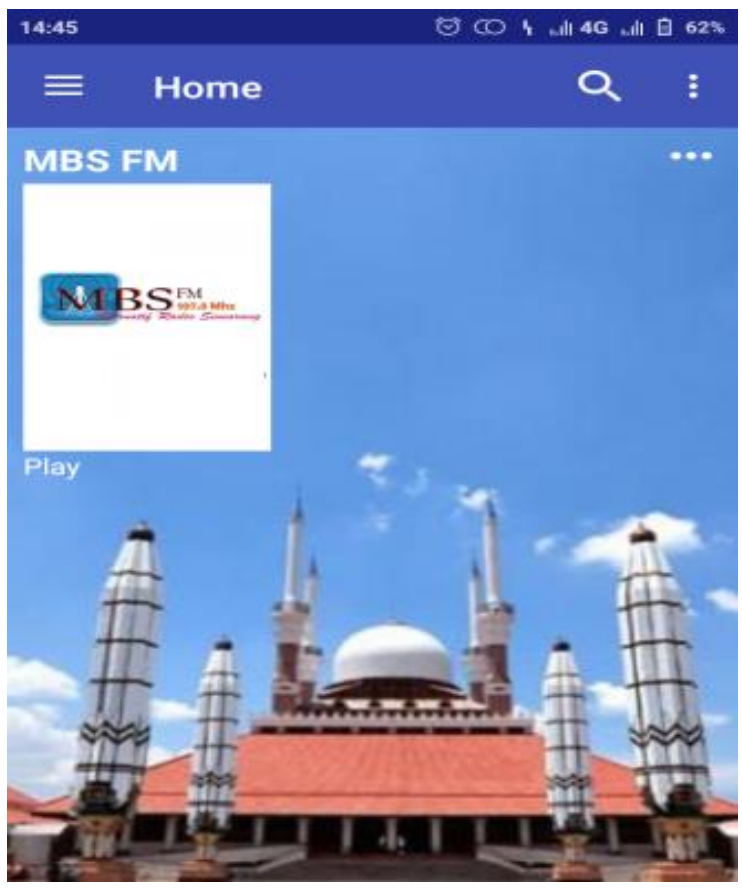

Gambar 2.0 menunjukan template

2. Icon dan Tombol Navigasi gambar

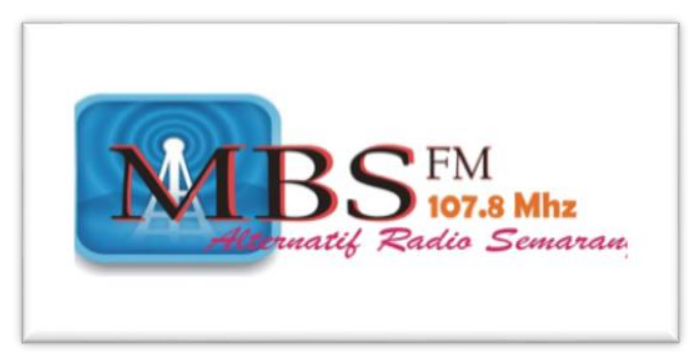

Gambar 2.1 menunjukan tampilan icon dan navigasi aplikasi radio android

b. Pembuatan aplikasi radio streaming berbasis android

Langkah dalam pembuatan aplikasi radio streaming berbasis android yang pertama yaitu masuk ke web khusus pembuatan aplikasi android yang bernama Apps Geyser www.appsgeyser.com. Untuk dapat mengakses web pembuatan aplikasi 
tersebut langkah selanjutnya yaitu log in terlebih dahulu melalui e-mail. Setelah berhasil log in ke apps geyser klik tombol "create app" yang berada di pojok kanan atas. Setelah itu muncul beberapa tampilan icon aplikasi yang ingin dibuat, kemudian pilih icon"media radio player". Setelah memilih icon radio player, akan muncul tampilan "Template Description" kemudian klik tombol "Next". Setelah itu masukkan data dan link streaming radio MBS.FM 107.80. Kemudian menginput gambar untuk "template, icon gambar dan tombol navigasi" yang terdapat pada gambar 1.0, 1.1, dan 1.2. Setelah tahapan diatas selesai, simpan data radio dan link streaming radio MBS.FM setelah itu aplikasi siap di publish ke playstore, dan siap untuk digunakan.

Gambar 2.2 tampilan pertama saat membuka apps geyser

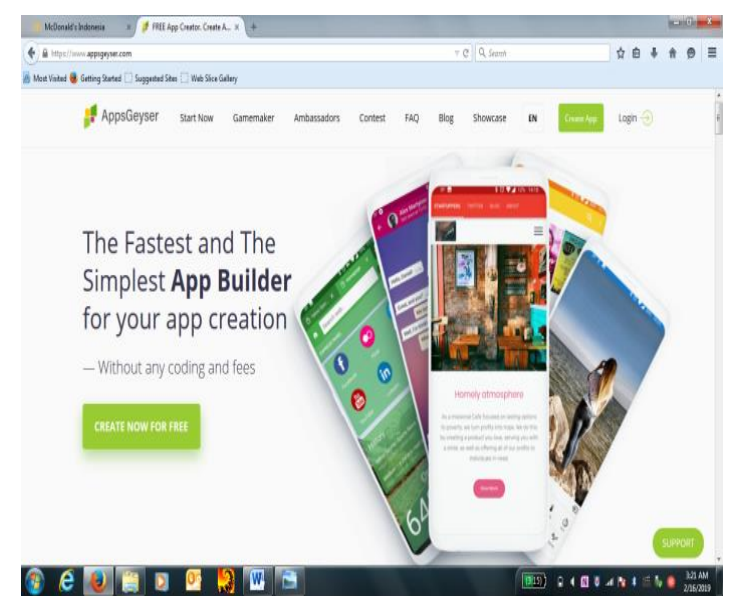

Gambar 2.4 tampilan icon setelah klik "create app"
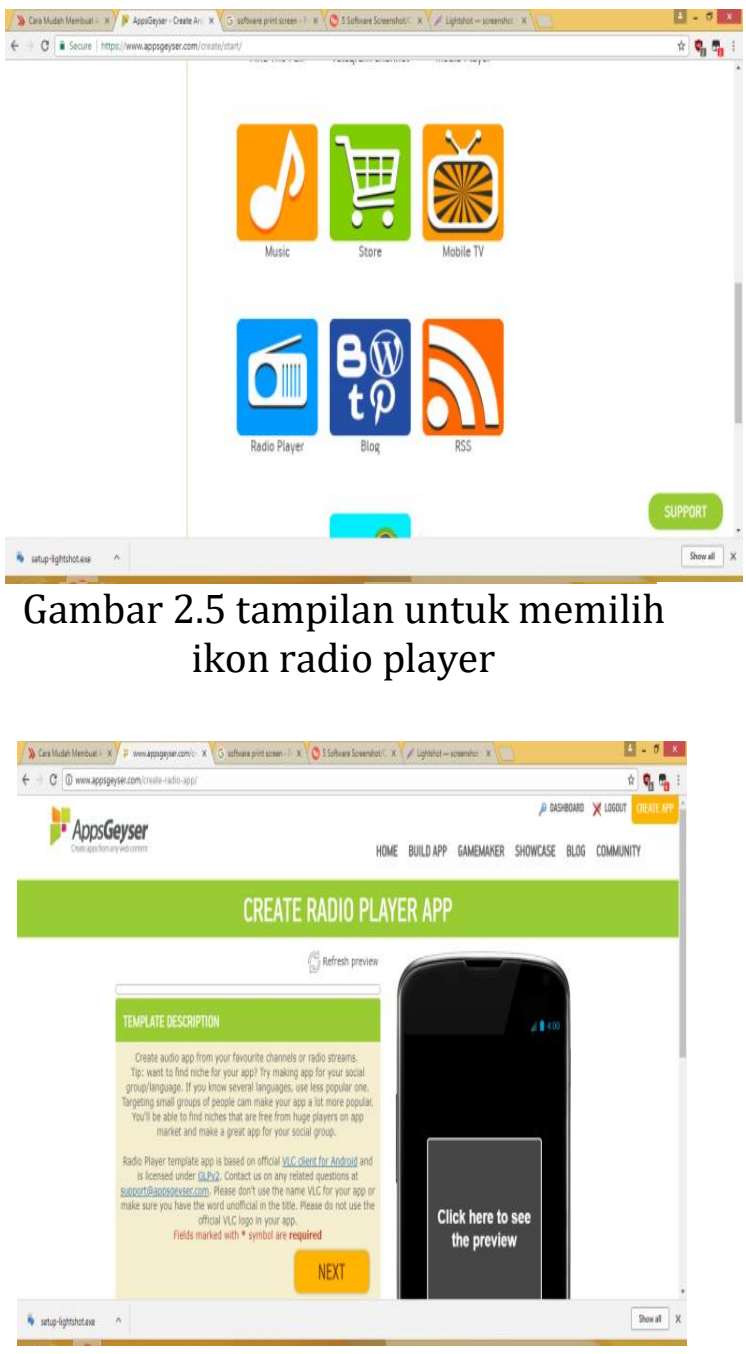

Gambar 2.7 tampilan template description lalu klik tombol "Next" 


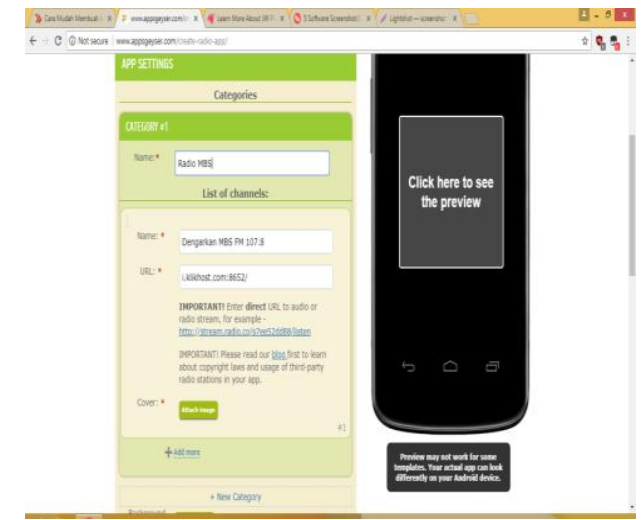

Gambar 2.8 tampilan menginput data dan link streaming Radio MBS.FM

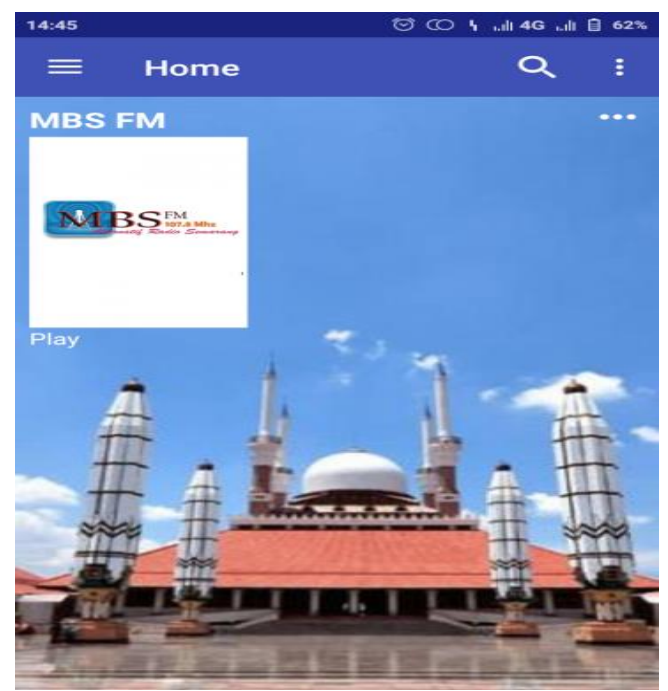

Gambar 2.9 tampilan aplikasi android radio MBS.FM yang siap digunakan

a. Pengujian system

Setelah melakukan berbagai persiapan dan settingan, langkah selanjutnya adalah melakukan percobaan siaran streaming pada aplikasi android radio MBS FM dengan tahapan sebagai berikut:

Pertama, jalankan sofware ZaraRadio yang telah terhubung ke mixer dan microphone untuk melakukan siaran seperti biasanya. Kedua, jalankan pula sofware edcast yang sudah di setting sesuai dengan konfigurasi yang telah dijelaskan diatas. Setelah persiapan tersebut dilakukan radio siap onair. Pada saat radio MBS melakukan siaran peneliti melakukan obervasi melalui smartphone yang sudah terinstal aplikasi android radio MBS.FM.

Produk aplikasi android radio MBS FM telah selesai didesain. Namun, dalam setiap produk pastilah terdapat kelebihan dan kekurangan. Kelebihan dari produk aplikasi radio ini ialah pada prosedur operasionalnya yang mudah. Setelah didesain sedemikian rupa sebagaimana pada pembahasan desain awal produk, pada operasionalnya hanya tinggal menjalankan aplikasi ZaraRadio sebagai software utamanya dalam melakukan siaran, kemudian penyiar juga menjalankan aplikasi edcast untuk mentransfer audio ke streamer agar dapat mentransfer ke aplikasi android. Maka secara otomatis siaran melalui jaringan FM dan streaming sudah berjalan. Sedangkan kelemahan pada produk streaming ini ialah suara yang didengarkan pada channel streaming mengalami delay yang cukup lama yaitu sekitar 15-20 detik. Kelemahan lain yaitu system jaringan internet pada aplikasi edcast yang tidak mendukung untuk menggunakan jaringan internet mikrotik sehingga peneliti menggunakan jaringan internet modulator demodulator (modem) untuk menjalankan streaming radio pada aplikasi edcast. Kelemahan yang lain yaitu jaringan sebelumnya pada 
streaming radio MBS.FM terbatas, hanya 100 pendengar saja diwaktu bersamaan. Karena peneliti sebelumnya mengambil jenis layanan streaming paket SH-1 yang ditawarkan oleh pihak KlikHost.com. Hal ini berarti pendengar ke 101 yang ingin mendengar siaran streaming radio MBS tidak dapat mendengarkan siaran. Demikianlah kelebihan dan kekurangan aplikasi android radio MBS FM Fakultas Dakwah dan Komunikasi UIN Walisongo Semarang. Walaupun terdapat beberapa kekurangan, peneliti berharap dapat memberikan sumbangan yang bermanfaat khususnya bagi radio MBS dan bagi mahasiswa UIN Walisongo pada umumnya. Produk aplikasi android ini dioperasionalkan secara langsung, penyiar dan crew radio MBS.FM sangat berperan penting dalam keberhasilan siaran streaming. Pemeliharaan dilakukan dengan cara menjaga perangkat lunak yang digunakan untuk siaran streaming tetap berjalan dengan baik di dalam komputer, sehingga pemeliharaan komputer juga harus dilakukan, dan menjaga kestabilan jaringan internet agar siaran streaming pada aplikasi tersebut berjalan dengan lancar.

\section{F. Kesimpulan}

Proses perancangan aplikasi android radio MBS FM telah selesai.
Pada bagian ini dilakukan uji coba siaran melalui aplikasi yang telah dibuat. Uji coba siaran ini dimaksudkan untuk mengetahui tingkat keberhasilan perancangan aplikasi android radio streaming MBS FM yang dilakukan. Aplikasi radio MBS FM berbasis android memiliki beberapa kelebihan, antara lain: Aplikasi radio MBS FM ini mempermudah pendengar untuk mendengarkan radio MBS FM tanpa adanya batasan jangkauan, Aplikasi radio MBS FM ini merupakan media untuk mendengarkan radio yang disajikan dalam smartphone android dengan penggunaan yang mudah, Aplikasi radio MBS FM ini dapat di install pada semua jenis smartphone android dan bekerja dengan baik, Aplikasi radio MBS FM ini sudah tersedia di play store.

Kekurangan Produk Aplikasi radio MBS FM berbasis android memiliki beberapa kekurangan, antara lain, Aplikasi radio MBS FM ini harus terhubung dengan jaringan internet, Aplikasi radio MBS FM ini sudah tersedia tampilan iklan yang mungkin untuk sebagian user sifatnya mengganggu. Akan tetapi disisi lain menguntungkan pengembangan secara komersil, Jangka waktu delay tergantung kondisi jaringan internet. 


\section{REFERENCES}

Akbar, Sa'dun. 2013. Instrumen Perangkat Perangkat Pembelajaran. Bandung: PT. Remaja Rosdakarya Offset

Arikunto, Suharsimi. 2006. Prosedur Penelitian Suatu Pendekatan Praktek, Jakarta: Rineka Cipta.

Fatmasari,Ningrum. 2007. Sukses Menjadi Penyiar, Scriptwriter \& Reporter Radio. Jakarta: Penebar Swadaya.

Hamid, Hamdani. 2013 Pengembangan Sistem Pendidikan di Indonesia. Bandung : Pustaka Setia.

Haryati, Sri. 2012. Research and Development (R\&D) Sebagai Salah satu Model Penelitian dalam Bidang Pendidikan. Vol.37 N0.1,15 September 2012

Majid, Abdul. 2005. Perencanaan Pembelajaran, Bandung: Remaja Rosdakarya.

Mufid, Muhammad. 2015. Komunikasi dan Regulasi Penyiaran. (Jakarta: Kencana)

Masduki. 2004. Menjadi Broadcaster Profesional. Jogjakarta: Lkis

Moleong, Lexy J. 2004. Metode Penelitian Kualitatif, Edisi Revisi, Bandung: Remaja Rosda Karya.

Morrisan. 2009. Manajemen Media Penyiaran. Jakarta: Kencana Prenada Media Group.

NS. Roymond H. Simamora, M.kep. 2009. Buku Ajaran Pendidikan Dalam Keperawatan. Jakarta : Kedokteran EGC

Syamsul, Asep dan M. Romli. 2009. Dasar-Dasar Siaran Radio . Bandung: Nuansa

Subagyo, Joko. 1991. Metodologi Penelitian Dalam Teori Dan Praktek, Jakarta: Rineka Cipta.

Sugiyono. 2009. Metode Penelitian Pendidikan (pendidikan Kuantitatif, Kualitatif dan R\&D): Bandung, Alfabeta

2011. Metode Penelitian Kuantitatif, Kualitatif dan R\&D. Bandung: Alfabeta

2012. Metode Penelitian pendidikan pendekatan kuantitatif, kualitatif, dan R\&D. Bandung: Alfabeta

2014. Metodologi Penelitian Kuantitatif, Kualitatif dan R\&D, Bandung: Alfabeta.

2016. Metodologi Penelitian Kuantitatif, Kualitatif dan R\&D, Bandung: Alfabeta

Umar, Husein. 2000.Business An Introduction, Jakarta : PT Gramedia Pustaka Utama,

Vivian. 2008. Teori Komunikasi. Jakarta: Kencana

Wardani. Diah, 2013, Media Relations Sarana Membangun Reputasi Organisasi, Jakarta: Graha Ilmu.

Widjaja. 2000. Ilmu Komunikasi. Jakarta: Rineka Cipta.

https://id.wikipedia.org/wiki/Radio (diakses pada tanggal 16 maret 2018, pukul 21.28)

WJIT : Walisongo Journal of Information Technology - Vol.1 No. 2 (2019) 
www.spengetahuan.com/2016/06/10-pengertian-aplikasi-menurut-para-ahlilengkap.html ,(diakses pada tanggal 07 april 2018 pukul 21.28).

https://Rumahkuta.blogspot.co.id/2013/06/pengertian Aplikasi.html?m=1 (diakses pada tanggal 09 april 2018 pukul 08.32).

http://vovworld.vn/id-ID/kotak-surat-anda/sejarah-pembentukan-dan-perkembanganradio-di-dunia-135613.vov.

https://pakarkomunikasi.com/sejarah-radio-di-indonesia

https://elib.unikom.ac.id/files/disk1/578/jbptunikompp-gdl-aamsitifat-28858-6unikom_a-i.pdf

http://www.berbagiinfo4u.com/2013/06/apa-itu-android.html 